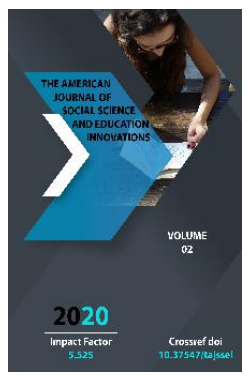

\title{
Comparing The Aspect Categories Of Action Verbs In Russian And English
}

\author{
Yangibaeva Iklima Ataxanovna \\ Student Of Philology Faculty, Urgench State University, Uzbekistan
}

Journal Website:

http://usajournalshub.c

om/index,php/tajssei

Copyright: Original

content from this work

may be used under the

terms of the creative

commons attributes

4.0 licence.

\section{ABSTRACT}

When comparing the aspect of one language to another one, there will be some compare and contrast sides from typological point of view. The main function of a verb is that of the predicate both languages. Verbs have almost the same grammatical categories in both the languages, including tense, person, inflections and exception is the category of gender. There have been a lot of researches and discussions about the on similarities in English and Russian grammar.

\section{KEYWORDS}

Comparative typology, suffix, prefix, perfective aspect, imperfective aspect, lexical meaning, grammatical category, non-continuous aspect, indicative mood, case, category of gender, tense, person, connotation.

\section{INTRODUCTION}

Aspect is a grammatical category that deals with how an action, event, state, done by a verb, extends over time. Perfective aspect is applied when referring to an event or state conceived as bounded and unitary, without reference to any flow of time during ("I cleaned the house"). Imperfective aspect is used for situations conceived as existing 
continuously or repetitively as time flows ("I was cleaning the house"; "I used to clean the house").

Typology of grammatical category is a system opposed to each other grammatical form with similar values. Members of the same grammatical category are the general grammatical meaning and differ in connotation. Grammatical categories are subdivided into morphological and syntactic groups. Between the morphological categories are distinguished, to illustrate, the type of grammatical categories, tenses, mood, person, gender, number, case, consistent expressions of these categories are characterized by the whole grammatical word classes. We call them parts of speech. Grammatical categories in Russian and English languages with a strong word formation and they might be represented by the forms of the same word within its paradigm, for instance, in the Russian language - the tense, the inclination, the number of the verb, case, gender adjective degrees of comparison.[1.86]

\section{MATERIALS AND METHODS}

Any grammatical category of verbs has a specific content and it can be usual division for some languages. The verb рисовать has specific content- a verb imperfective. That is why every word (especially with verbs)can have a number of grammatical meaning can be observed. In the Russian verb бежал the following grammatical meanings are observed: past tense meaning, singular, category of gender, unfinished form. $[1,87]$ In Russian, every verb belongs to either to the perfective or imperfective aspect. The main indicators of aspect in Russian are prefixes and suffixes (читать- прочитать, рисоватьнарисовать, писать- написать). In English the category of aspect is presented by forms of continuous and non-continuous aspects (I clean - I am cleaning). Perfective aspect in Russian is usually formed with the help of prefixes which not only change aspect forms, but also give new lexical meaning to the verb (нести- принести- вынести- занести). Every aspect form is a new word formation. In Russian, verbs with suffix Hy- in perfective aspect, usually denote a quick and sudden action like (нырять- нырнуть, толкатьтолкнут). In English in such cases, various words are used (to flap, to push, to dive). Imperfective aspect in Russian is usually formed with the help of suffixes (переписатьпереписывать, забить- забывать). They usually show repeated actions and we can easily know whether the action is finished or not. In English, the repetition of action is usually expressed with the help of prefix (write- rewrite, check- recheck, submit resubmit). In some cases, in Russian, only vowels in suffixes may change (пуститьпускать, решить- решать). In English in such cases only one verb is used and what you will see in dictionaries such verbs are given (пустить- пускать) 2 Russian verbs of perfective and imperfective aspects have 1 English equivalent like (получить- получать, receive). Though the category of aspect gives a characteristic to an action, this category is more identical in 2 languages. In English the category of continuous aspect has a most specific character than verbs in noncontinuous aspect.[2]

\section{RESULT AND DISCUSSION}

Verbs in continuous aspect show action in progress, whereas in non- continuous aspect, they denote actions as pure facts. In Russian, perfective aspect has more specific character that it does in English. It may express some state in the process of action. Usually the starting point (спел- запел). Imperfective 
aspect in Russian is more extensive in meaning than continuous aspect in English. The category of aspect in English is closely connected with the category of Tense and we can express the actions using Perfect and Continuous Tenses. The finite forms of verbs, of the indicative mood in Russian, maybe convey action in the past, present, or future. Past tense in Russian, is a specific category, because verbs in the past have no special endings (я - читал- он читал- мы читали- они читали) Verbs in the past in Russian have grammatical category of gender (он читалона читала) and this feature differs Russian, from other in the European languages and English among them. In English, past tense is divided into past- indefinite, past continuous, past perfect and past perfect continuous. Past Indefinite presents a pure grammatical category. While past continuous and past perfect continuous, present Tense and Aspect forms. Present Tense, in some cases coincides in meaning, in Russian and English. It is used to express 3 types of actions .

1. An action at a moment of speech. (I see him at school)

2. Repeated action. (They go to the beach every summer)

3. An action going on without any interval (Месяц светит ,но не греет. The moon shine, but doesn't give any warmth.)Present tense in English is divided into - Present Indefinite, Present Continuous, Present Perfect and resent Perfect Continuous. But if present Indefinite is used to denote future action in subordinate close of time and condition after conjunctions (as soon as ,...) in Russian - future tense is used in both sentences (если погода будет- мы поедем) In both languages, verbs of motion may denote future action (the rain arrives at 5) in English present continuous maybe also used in such cases

(he is leaving soon) If completeness of an action is underlined, in English - present perfect is used ( he will know the poem by hard, if he has heard it twice) In Russian future tense is used in such cases.

\section{CONCLUSION}

Aspect is often confused with the closely related concept of tense, because they both express data about time. While tense relates the time of referent to some other time, generally the speech event, aspect conveys other temporal information, such as duration, completion, frequency, since it relates to the time of events. Thus tense refers to temporally when while aspect refers to temporally how [3]. Aspect can be said to describe the texture of the time in which a situation occurs, such as a single point of time, a continuous range of time, a sequence of discrete points in time, etc., whereas tense indicates its location in time. Grammatical aspect is a formal property of a language, distinguished through overt inflection, derivational affixes, or independent words that serve as grammatically required markers of those aspects. For example, English marks the continuous aspect with the verb to be coupled with present participle and the perfect with the verb to have coupled with past participle [4]. Even languages that do not mark aspect morphologically or through auxiliary verbs, however, can convey such distinctions by the use of adverbs or other syntactic constructions.

\section{REFERENCES}

1. Arakin V.D. Comparative typology of English and Russian languages. - L., 1979. 
Doi: https://doi.org/10.37547/tajssei/Volume02Issue08-56

2. Comparative Typology of English, Uzbek and Russian Languages, M.I.Rasulova, Z.I.Shukurova, 2017

3. Bernard Comrie, 1976. Aspect. Cambridge University Press

4. Gabriele, Alison (2008). "Transfer and Transition in the L2 Acquisition of Aspect". Studies in Second Language Acquisition: 6 